\title{
Comprehensive study of ovarian tumours in Kathmandu University Hospital
}

\section{Tamrakar SR', Makaju R², Shrestha A', Kayastha $\mathrm{S}^{3}$}

'Suman Raj Tamrakar, Associate Professor, Department of Obstetrics and Gynecology; ${ }^{2}$ Ramesh Makaju, Associate Professor, Department of Pathology; ${ }^{1}$ Abha Shrestha, Associate Professor, Department of Obstetrics and Gynecology; ${ }^{3}$ Suresh Kayastha, Lecturer, Department of Obstetrics and Gynecology, Dhulikhel Hospital - Kathmandu University Hospital , Kavre, Nepal.

\begin{abstract}
Background: Ovarian tumours account for $15 \%$ to $25 \%$ of all primary malignancy and the leading cause of death from gynaecolgical malignancies. There are limited publications related to ovarian tumours from Nepal. Ovarian related surgeries are the common surgeries in Kathmandu University Hospital. This study aims to provide basic information related to ovarian tumours from this geographical region of Nepal.

Objectives: To review the nature of ovarian problems and certain socio-demographic information namely: caste, age, address and co-morbid condition of the patients presenting with ovarian problems.

Methodology: This is a retrospective study of patients seeking surgical treatment of ovarian lesions in Kathmandu University Hospital from January 1, 2011 to June 30, 2018. This study was undertaken by reviewing the inpatient, outpatients and OT records in the Department of Obstetrics and Gynaecology and the records from Department of Pathology. All the files and computer records were reviewed and analyzed for nature of ovarian problems and certain demographic variables.

Results: Out of the 860 cases, about $61 \%$ were non-neoplastic while benign ovarian tumours and malignant ovarian tumours were $35 \%$ and $3.7 \%$ respectively. Almost one third of the cases were of Brahmin/Chhetri (37.3\%) and 58.3\%of the patients were from Kavre district. Mean age of the patients with ovarian problems was 34.89 \pm 11.15 years (range 12-72 years). There was no statistically significant difference between the mean age of patients with non-neoplastic ovarian lesions and neoplastic ovarian lesions ( $p$ value $=0.3371$ ). There was statistically significant difference between the mean age of patients with benign ovarian tumours and malignant ovarian tumours ( $p$ value $=0.0001$ ). And malignant ovarian tumours were significantly high among patients above 41 years in comparison to benign ovarian tumours of same age group ( $p$ value $=0.0008$ ). Out of 32 , ten malignant ovarian tumours occurred in relatively young age group. Of the 860 ovarian lesions, 438 and 422 ovarian lesions were removed through open technique and laparoscopic techniques respectively. Mature cystic teratoma (64.1\%) was the commonest benign tumor and serous cyst adenocarcinoma (43.8\%) was the commonest malignant tumour in this study.

Conclusion: Ovarian tumours are one of the gynaecological diagnoses in Kathmandu University Hospital. If only ovarian neoplasms are considered, most of the ovarian tumours are benign and few are malignant. Minimal invasive surgeries are possible, except that for malignant ovarian tumours.
\end{abstract}

Key words: Adenocarcinoma; Laparoscopy; Ovarian tumour; Teratoma.

DOI: https://doi.org/10.3126/jkmc.v7i4.23322

\section{INTRODUCTION}

t has been estimated that ovarian tumors account for $15 \%$ to $25 \%$ of all primary malignancy in female

Address for correspondence

\section{Dr. Suman Raj Tamrakar}

Associate Professor, Department of Obstetrics and Gynecology

Dhulikhel Hospital Kathmandu University Hospital, School of Medical Sciences (KUSMS), Dhulikhel, Kavre

E-mail: drsuman3947@gmail.com genital organ'. Ovarian tumors are a complex wide spectrum of neoplasms involving a variety of histological tissues namely epithelial tissues, connective tissues or specialized hormone secreting germinal and embryonal cells ${ }^{2}$. It is the leading cause of death from gynaecolgical malignancies, accounting $50 \%$ of deaths that occur at all age $^{3}$.

Relative frequency of different ovarian tumor was different for western world and Asian countries. For 
example, surface epithelial tumors comprised $50-55 \%$ of all ovarian tumors and their malignant counterpart for approximately $90 \%$ of all ovarian cancers in western world where as this figure was $46-50 \%$ and $70-75 \%$ respectively in Japan. Likewise, mucinous tumors accounted for $12-15 \%$ and $20-23 \%$ of all ovarian tumors in western world and Japan respectively. Germ cell tumors comprised $30 \%$ of primary ovarian tumors and malignant germ cell tumors accounted for $3 \%$ of all ovarian cancers in western world ${ }^{4}$.

The cancer incidence per 100,000 in males was 12.8 in 2003 and 25.8 people in 2012. Similarly, in females, the crude incidence rate was 15.1 in 2003 and 26.7 per 100,000 in 2012. This retrospective study indicated that the incidence in female cancer was higher than the incidence in male cancer ${ }^{5}$. In a retrospective study $(n=240)$ by Khan $G M$ et al found $60.42 \%$ cancer in female patients. Of them, $11.11 \%$ had ovarian cancer ${ }^{6}$. Age standardized rate (ASR) of ovarian cancer was 2.09 per 100,000 while age specific incidence of ovarian cancers was highest $(13.46$ per 100,000$)$ in age group of $50-59$ years ${ }^{7}$.

There were limited publications related to ovarian tumours from $\mathrm{Nepa}^{3,8-13}$. And these studies were focused either in the limited causal factors or with small sample size. A study $(n=60)$ conducted in same institute focusing various tumours, based on histopathological analysis ${ }^{14}$.

Ovarian tumours were the one of the diagnoses in Gynaecology outpatient department (OPD). And the ovarian related surgeries comprised significant portion of gynaecological surgeries in Kathmandu University Hospital (KUH). Hence this study aimed to review the nature of ovarian problems and certain sociodemographic information of the patients namely caste, age, address and co-morbid condition of the patients presenting with ovarian problems.

\section{METHODOLOGY}

A retrospective study was undertaken by including the patients who underwent surgical treatment for the ovarian lesions in KUH from January 1, 2011 to June 30,2018 . This study was undertaken by reviewing the Inpatient, outpatients and OT records in the Department of Obstetrics and Gynaecology and the records from Department of Pathology. All the files and computer records were reviewed and analyzed.

All the clients or patients with ovarian lesions who underwent surgical treatment in $\mathrm{KUH}$ are included in the study. The ovarian pathology and certain sociodemographic information namely: caste, age, address and co-morbid condition of the patients were analyzed.

Most of the ovarian cysts were removed by laparoscopic technique followed by open technique (laparotomy). And most of the ovarian tumours were removed through open technique (i.e. total abdominal hysterectomy (TAH) with or without bilateral salpingo-oophprectomy). Few ovarian cysts were removed during lower segment caesarean section (LSCS) while certain ovarian tumours (diagnosed or suspected malignant) were removed as part of staging laparotomies. In this study, both of these procedures (LSCS and staging laparaotomy) were considered as open technique. Likewise, certain ovarian tumours were removed through laparoscopic assisted vaginal hysterectomy (LAVH) or total laparoscopic hysterectomy (TLH). These were considered as laparoscopic technique in this study.

Ethical clearance was taken from the hospital research committee (IRC-KUSMS \# 134/18) prior to data collection. All data were analyzed by SPSS 16 version using appropriate statistical tools.

\section{RESULTS}

Almost one third of the cases were of Brahmin/Chhetri (37.3\%) and Newar (31.7\%) followed by about a quarter were of other Janajati (mostly Tamang) (24.8\%), lower caste (4.7\%) and Madhesi (1.5\%).

Though there was no statistical difference between the mean age of patients with non-neoplastic ovarian lesions and neoplastic ovarian lesions. There was statistical difference between the mean age of patients with benign ovarian tumours and malignant ovarian tumours (Table 1).

Malignant ovarian tumours were significantly high among patients above 41 years in comparison to benign ovarian tumours of same age group $(p=0.0008)$ (Table 2). Out of 32, ten malignant ovarian tumours occurred in relatively young age group (four mucinous cystadenocarcinoma at 23, 25, 30 and 32 years; two yolk sac tumours at 17 and 24 years; two immature teratoma at 28 and 29 years; one papillary serous adenocarcinoma at 24 years and one dysgerminoma at 26 years) in our study. More than half of the patients were from Kavre district $(58.3 \%)$, followed by Kathmandu valley (particularly Bhaktapur) (21,5\%), neighbouring districts like Sindhupalchowk, Dolakha, Ramechhap, Sindhuli (14.0\%) and other districts (6.3\%). 


\section{Co-morbid condition}

Of the 680 cases, 135 patients had other gynaecologocal pathologies (of them 104 had fibroids, 30 had medical problems (hypertension, hypothyroidism, diabetes, anemia, urinary tract infection, depression, dyslipidemia) and 18 had surgical problems. Laparoscopic appendectomy (8 cases), cholecystectomy (6 cases), hernia repairand cystoscopy (one each) were performed along with primary surgical conditions.

Of the 860 ovarian lesions, 438 and 422 ovarian lesions were removed through open technique and laparoscopic techniques respectively.

Table 1: Distribution of mean age of the patients with ovarian lesions

\begin{tabular}{lcc}
\hline Ovarian pathology $(\mathrm{n}=\mathbf{8 6 0})$ & Mean age (years) & p value (95\% confidence interval) \\
Non-neoplastic ovarian lesions $(n=527)$ & $35.15 \pm 9.88$ & 0.3371 \\
Neoplastic ovarian lesions $(n=333)$ & $34.40 \pm 12.92$ & $(-0.7842$ to 2.2842$)$ \\
Benign ovarian tumours $(n=301)$ & $33.59 \pm 12.47$ & 0.0001 \\
Malignant ovarian tumours $(n=32)$ & $42.72 \pm 14.26$ & $(5.5036$ to 14.7564) \\
\hline
\end{tabular}

Table 2: Age group distribution of patients with different ovarian pathology

\begin{tabular}{|c|c|c|c|c|}
\hline Age group (years) & $\begin{array}{c}\text { Non-neoplastic ovarian } \\
\text { lesions }(n=527)\end{array}$ & $\begin{array}{l}\text { Benign ovarian } \\
\text { tumours }(n=301)\end{array}$ & $\begin{array}{l}\text { Malignant ovarian } \\
\text { tumours }(n=32)\end{array}$ & $\begin{array}{l}\text { Total ovarian cases } \\
\qquad(\mathrm{n}=\mathbf{8 6 0})\end{array}$ \\
\hline 20 or below & $8.3 \%$ & $13.3 \%$ & $3.1 \%$ & $9.9 \%$ \\
\hline $21-30$ & $28.1 \%$ & $34.9 \%$ & $25.0 \%$ & $30.3 \%$ \\
\hline $31-40$ & $26.9 \%$ & $26.6 \%$ & $18.8 \%$ & $26.5 \%$ \\
\hline $41-50$ & $34.0 \%$ & $14.3 \%$ & $18.8 \%$ & $26.5 \%$ \\
\hline $51-60$ & $2.5 \%$ & $8.0 \%$ & $28.1 \%$ & $5.3 \%$ \\
\hline 61 or above & $2.0 \%$ & $3.0 \%$ & $6.2 \%$ & $1.4 \%$ \\
\hline
\end{tabular}

Table 3: Different types of ovarian pathology on the basis of histopathologocal examination

\begin{tabular}{|c|c|c|c|}
\hline Type of ovarian lesion & Pathological diagnosis & Frequency & Percent \\
\hline \multirow{6}{*}{$\begin{array}{l}\text { Non-neoplastic ovarian } \\
\text { lesions }\end{array}$} & Follicular/simple cyst & 212 & 24.7 \\
\hline & Endometriotic cyst & 195 & 22.7 \\
\hline & Corpus luteal cyst & 107 & 12.4 \\
\hline & Poly cystic ovarian syndrome (PCOS) & 11 & 1.3 \\
\hline & Ovarian ectopic & 2 & 0.2 \\
\hline & Total & 527 & 61.3 \\
\hline \multirow{8}{*}{ Benign ovarian tumours } & Serous cyst adenoma & 48 & 5.6 \\
\hline & Mucinous cyst adenoma & 43 & 5.0 \\
\hline & Brenner tumour & 4 & 0.5 \\
\hline & Clear cell tumour & 1 & 0.1 \\
\hline & Thecoma/fibroma & 7 & 0.8 \\
\hline & Sertoli-Leydig cell tumour & 5 & 0.6 \\
\hline & Mature cystic teratoma & 193 & 22.4 \\
\hline & Total & 301 & 35.0 \\
\hline \multirow{9}{*}{ Malignant ovarian tumours } & Serous cyst adenocarcinoma & 14 & 1.6 \\
\hline & Mucinous cyst adenocarcinoma & 7 & 0.8 \\
\hline & Endometroid carcinoma & 3 & 0.3 \\
\hline & Dyserminoma & 4 & 0.5 \\
\hline & Yolk sac tumour & 2 & 0.2 \\
\hline & $\begin{array}{l}\text { STUMP (Smooth Muscle Tumour of } \\
\text { Uncertain Malignant Potential) }\end{array}$ & 1 & 0.1 \\
\hline & Secondary metastasis & 1 & 0.1 \\
\hline & Total & 32 & 3.7 \\
\hline & Grand total & 860 & 100.0 \\
\hline
\end{tabular}




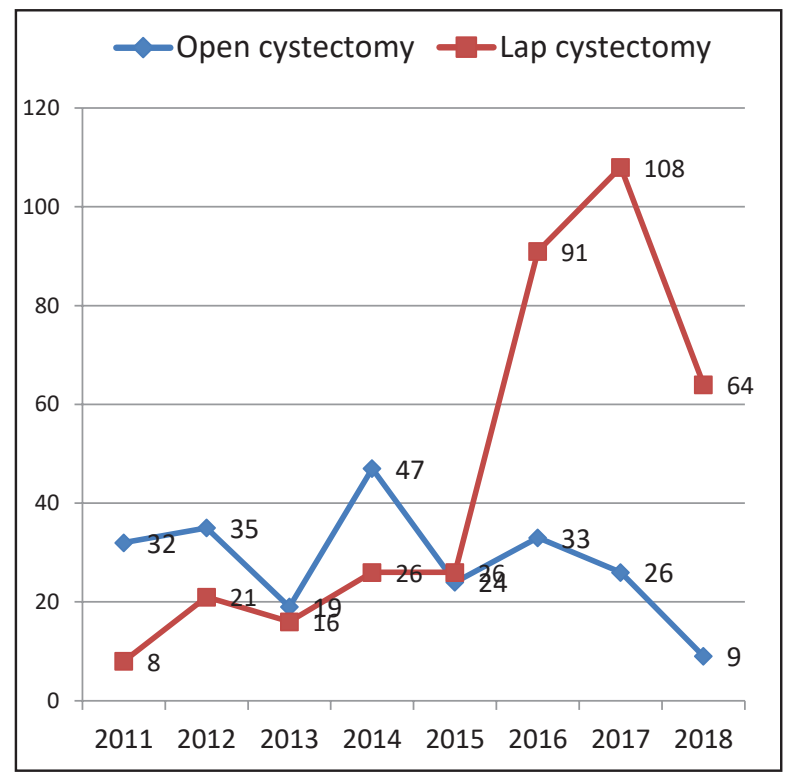

Figure 1: Year-wise distribution of route of cystectomies

\section{DISCUSSION}

Classification of ovarian tumours was done according to World Health Organisation ${ }^{4}$. Out of 860 cases, almost two third cases are non-neoplastic while benign ovarian tumours and malignant ovarian tumours are 35\% and $3.7 \%$ respectively. Of 333 neoplastic ovarian tumours, benign ovarian tumours are $90.4 \%$ and malignant ovarian tumours are $9.6 \%$. Studies by Kayastha $S$ et al and Pudasaini $S$ et al showed similar findings with benign vs malignant ovarian tumours of $90 \%$ and $10 \% \& 87.3 \%$ and $12.7 \%$ respectively) ${ }^{10,15}$.

In a study of ovarian neoplasms ( $\mathrm{n}=60$ cases) from same institute $(\mathrm{KUH})$, there were 16 (26.7\%) neoplasm of the ovary. Of them, 11 were benign ovarian tumours (ninemature cystic tertoma, one serous papillarycyst adenoma and one mucinous cystadenoma) and five were malignant ovarian tumours (consisting of two serous cystadenocarcinoma, two mucinous cyst adenocarcinoma and one mixed mucinous and serous cystadenocarcinoma) ${ }^{14}$.

Mature cystic teratoma (193, 64.1\%), serous cyst adenoma (48, 15.9\%) and mucinous cyst adenoma $(43,14.3 \%)$ were common benign ovarian tumours and serous cystadenocarcinoma (43.8\%) and mucinous cystadenocarcinoma (21.9\%) are common malignant ovarian tumours in this study which are similar to other study findings of Nepal (Table 4).

Like other studies ${ }^{3,9,16-18}$ mature cystic teratoma was the commonest benign tumor and serous carcinoma was the commonest malignant tumor in this study.

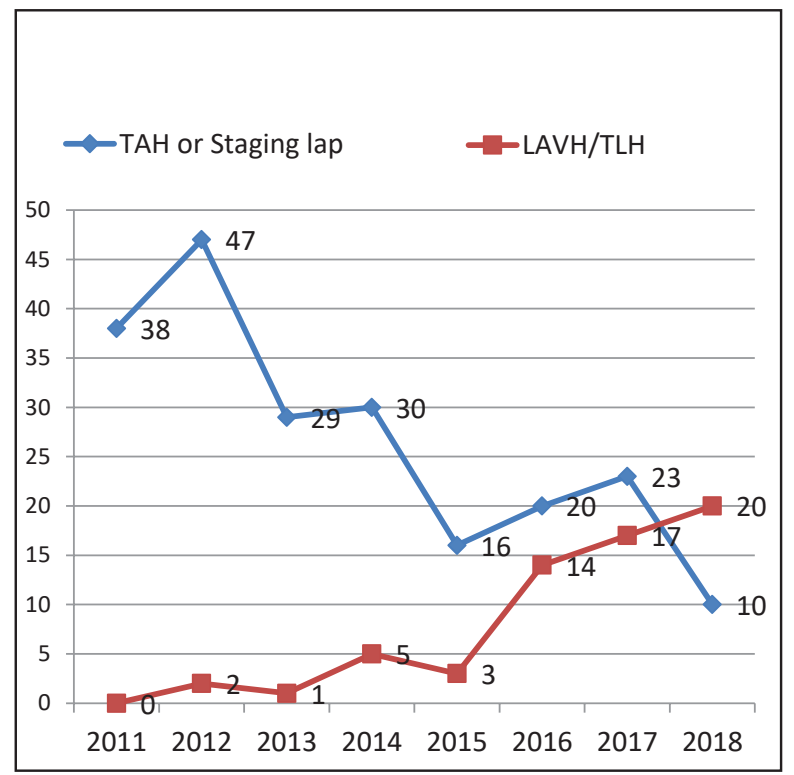

Figure 2: Year-wise distribution of route of hysterectomies

A female's risk at birth of having ovarian tumor sometime in her life is $6-7 \%$. Two third of ovarian tumors occur in women of reproductive age group?. We have also experienced same findings with $59.7 \%$ of ovarian tumours among the patients of 21 to 40 years. Likewise, studies by Pilli GS et al and Merino MJ et al also showed that most ovarian tumors occur in women of reproductive age group with peak incidence between 21-40 years ${ }^{19,20}$.

Benign ovarian tumors occur in all age group where as malignant ovarian tumors are more common in elderly ${ }^{20,21}$. Malignant germ cell tumors are most common ovarian cancers among children and adolescent females ${ }^{4}$. In a study by Pradhan A found that younger age involvement was an interesting observation made in relation to metastatic tumors ${ }^{12}$.

Studies by Kayastha $\mathrm{S}$ et al, $\mathrm{R}$ Jha et al, Pudasaini $\mathrm{S}$ et al and Pradhan A et al showed bilateral ovaries were involved in 12 cases (12.6\%), 21 cases (13.0\%), 19 cases (18.6\%)and 18 cases (22\%) respectively ${ }^{9,10,12,15}$. In this study, there were 68 such bilateral ovarian cases (7.9\%). Of them 34 cases were non-neoplastic ovarian lesions.

Bilateral in distribution was more a feature of malignant tumors. In a study by Jha R et al, 42.3\% (11/26) malignant tumors and only $6.7 \%$ (9/135) benign tumors were bilateral in distribution ${ }^{9}$. More than half malignant ones $12(52 \%)$ were bilateral in distribution ${ }^{22}$. Eleven benign cases $(16.6 \%)$, one borderline case $(50 \%)$ borderline and five malignant cases $(33.3 \%)$ were bilateral in 
distribution. The bilateral tumors were serous tumors (9), mature cystic teratoma (4), metastatic tumors (3), mucinous cystadenoma (1) and mixed seromucinous $(1)^{12}$. In contrast to these studies, we have found similar bilateral distribution in both types of tumours with $10.3 \%$ in benign and $9.4 \%$ in malignant ovarian tumours.

The incidence of ovarian tumours during pregnancy is $1 \%$ which is comparable to other series ${ }^{3}$. Ovarian tumours in pregnancy is usually diagnosed in the first and second trimester of pregnancy ${ }^{23}$. Pregnancy was associated with five cases (6.0\%), and they were serous cystadenoma (2), mature cystic teratoma (2) and immature teratoma (1) ${ }^{12}$. In our study, 16 ovarian lesions removed during LSCS. We had two cases of ovarian ectopic in this period.
Commonest complications of the ovarian tumour were torsion 12 (12.6\%), 11 (11.6\%) infection of the cyst, 9 (9.5\%) had malignancy and $3(3.2 \%)$ had intracystic haemorrhage ${ }^{10}$. Torsion was seen in $6.8 \%{ }^{22}$.We have found torsion in 73 (8.5\%) cases and rupture or haemorrhage in seven cases. We had experienced one case of xanthogranuloma salpingitis and another case of actinomycosis.

Most of the studies showed ovarian tumours were removed through open technique (laparotomy) 3,8-13,22. But in $\mathrm{KUH}$, minimal invasive gynaecological surgeries are being regularly performed for ovarian problems since early years of its establishment (Figure 1 and 2). We turned 19 cases of laparoscopic procedures into open for adhesion due to sequelae of endometriosis or pelvic inflammatory disease (14), larger size of the dermoid cyst (3) and ovarian abscess (2).

Table 4: Different studies of ovarian pathology in Nepal

\begin{tabular}{|c|c|c|c|c|}
\hline Study & Duration & $\begin{array}{l}\text { Mean age } \\
\text { (range) (years) }\end{array}$ & Benign & Malignant \\
\hline $\begin{array}{l}\text { Amatya A et } \\
\mathrm{al}^{8}(\mathrm{n}=80)\end{array}$ & $\begin{array}{l}\text { Jan } 1999 \text { to } \\
\text { Jan } 2008\end{array}$ & (15 to 19 ) & $\begin{array}{l}\mathrm{GCT}^{*}(59,73.7 \%) \\
\mathrm{SET}^{\dagger} 18(22.58 \%) \\
\text { Of all GCTs, mature cystic } \\
\text { teratoma }(45,76.3 \%)\end{array}$ & $\begin{array}{l}(19,23.7 \%) \\
\text { Mucinous adenocarcinoma (1), Clear cell } \\
\text { carcinoma (1), } \\
\text { Granulosa cell tumor (3), Immature } \\
\text { terratoma (7), } \\
\text { Endodermal sinus tumor (3), Mixed germ } \\
\text { cell tumors (2) and Dysgerminoma (2) }\end{array}$ \\
\hline $\begin{array}{l}\text { Pradhan A etal }{ }^{12} \\
(n=83)\end{array}$ & $\begin{array}{l}\text { Jan to Dec } \\
2006\end{array}$ & $\begin{array}{l}39.1 \\
(10 \text { to } 86)\end{array}$ & $\begin{array}{l}\text { Benign }(66,79.5 \%) \text { and } \\
\text { Borderline }(2,2.4 \%) \\
\operatorname{GCT}(33,50 \%) \text {, } \\
\text { SET }(31,47 \%) \text { and } \\
\operatorname{SCST}^{\ddagger}(2,3 \%) \text {. }\end{array}$ & $\begin{array}{l}\text { Malignant }(15,18.1 \%) \\
\text { Primary- }(12,80 \%) \text {, } \\
\text { Secondary - }(3,20 \%) \\
\text { Surface epithelial tumors }(6,40 \%) \\
\text { GCT }(5,33 \%), \text { Metastatic tumors }(3,20 \%) \\
\text { and SCST }(1,7 \%)\end{array}$ \\
\hline $\begin{array}{l}\text { Kayastha } S^{10} \\
(n=95)\end{array}$ & $\begin{array}{l}\text { Jan } 2006 \text { to Jul } \\
2008\end{array}$ & $\begin{array}{l}\text { (18 to } 70 \text { ) } \\
\text { Incidence } 9.5 \%\end{array}$ & $\begin{array}{l}86(90.5 \%) \\
\text { GCT }(26,27.4 \%) \\
\text { SET } 69(72.6 \%) \\
\text { Among SET } \\
\text { Serous cyst adenoma }(38, \\
40.0 \%), \\
\text { Mucinous cyst adenoma } \\
\text { (26, 27.4\%), } \\
\text { Brenner }(3,3.2 \%) \\
\text { Fibroma }(2,2.1 \%)\end{array}$ & $9(9.5 \%)$ \\
\hline $\begin{array}{l}\text { Bista } \\
\operatorname{KDB}^{13}(n=451)\end{array}$ & $\begin{array}{l}\text { Apr } 2009 \text { to } \\
\text { Apr } 2012\end{array}$ & 41.9 & $\begin{array}{l}370(82 \%) \\
\text { GCT } 215 \\
\text { SET } 151 \\
\text { Borderline }(14,3.1 \%)\end{array}$ & $\begin{array}{l}67(14.9 \%) \\
\text { Serous cyst adenocarcinoma(18,22.2\%) } \\
\text { Mucinous adenocarcinoma }(8,9.9 \%) \\
\text { Endometroid adenocarcinoma and } \\
\text { Dysgerminoma }(4,4.9 \%) \text { each }\end{array}$ \\
\hline
\end{tabular}


Table 4 cont ...

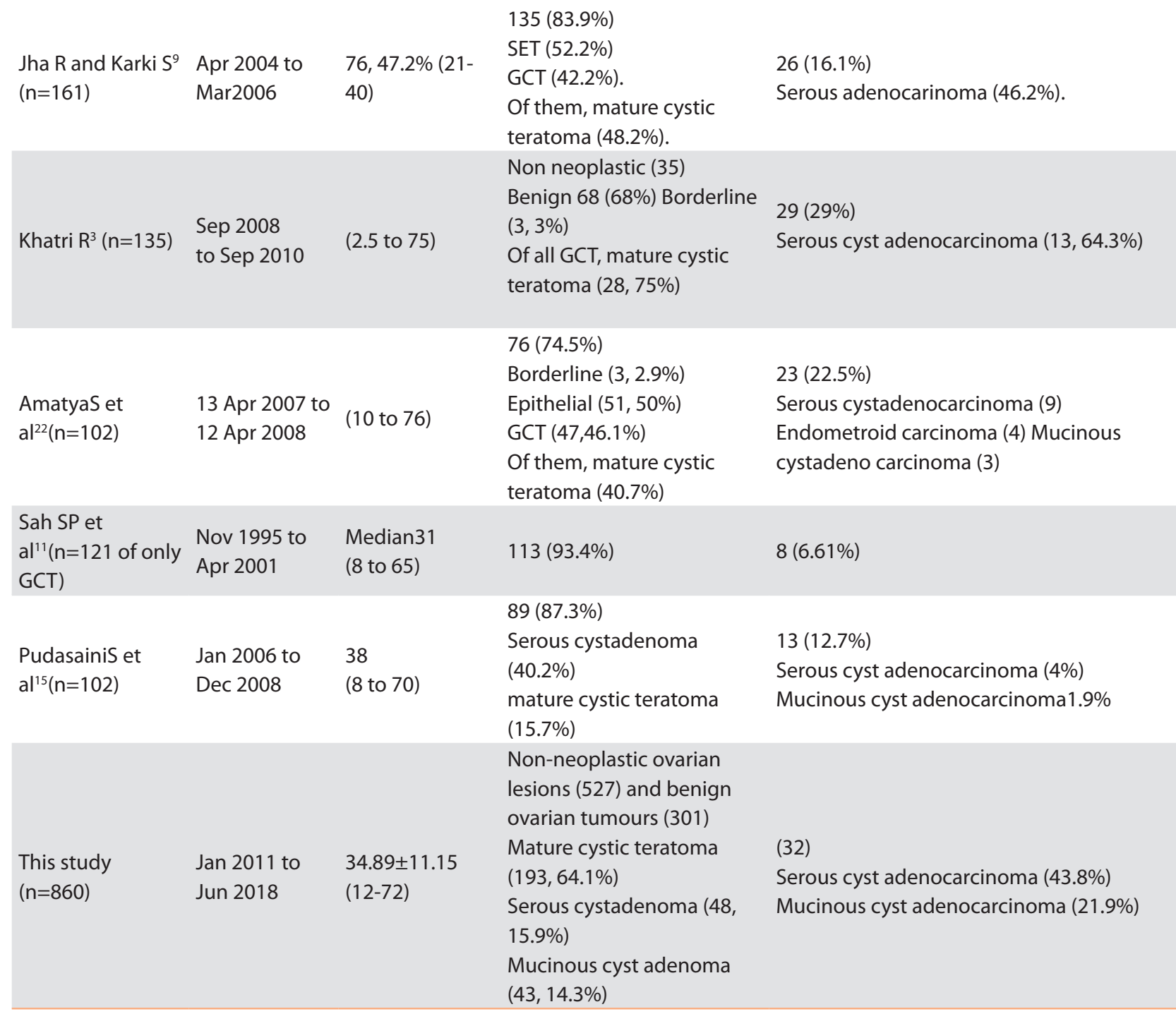

*GCT - Germ Cell Tumour, †SET - Surface Epithelial Tumour, ¥SCST - Sexcord Stromal Tumors

\section{CONCLUSION}

Ovarian problems are common in Kathmandu University Hospital. If only ovarian neoplasms are considered, most of the tumours are benign and few are malignant. There was statistical difference between the mean age of patients with benign ovarian tumours and malignant ovarian tumours. Though malignant ovarian tumours were significantly high among patients above 41 years of age, one third of the malignant ovarian tumours occurred in relatively young age group. Minimal invasive surgeries are possible, except that for malignant ovarian tumours.

\section{ACKNOWLEDGEMENTS}

The authors would like to thank all staffs of Department of Obstetrics and Gyanecology and Department of Pathology of KUH.

\section{REFERENCES}

1. Benson RC. Diagnosis and treatment. Current Obstet. Gynaecol. 1976; 1:236.

2. D K Edmonds. Gynecological disorders of childhood and adolescents. In: Dewhursts Textbook of
Obstetrics and Gynaecology for postgraduates. Sixth edition, London: Blackwell scientific publications; 1986. p. 12-6. [Full Text]

3. Khatri R. Clinicopathological analysis of ovarian tumours at Birendra Military Hospital. Medical J Shree Birendra Hospital. 2010;10:26-31.[DOI] 
4. Tavassoli FA, Devilee P. WHO classification of tumour. Pathology and genetics, Tumours of the breast and female genital organ. IARC press 2003. [DOI]

5. Poudel KK, Huang ZB, Neupane PR. Trends of cancer incidence in Nepal in the period 2003-2012. Asian Pac J Cancer Prev. 2016;17(4):2171-5. [DOI]

6. Khan GM, Thapa RK, Adhikari DS, Rajbhandari M, Dwa $P$, Shrestha $S$ et al. Cancer prevalence trend in central region of Nepal. Journal of Chitwan Medical College 2013;3(3):22-5. [DOI]

7. Poudel KK, Huang ZB, Neupane PR. Age specific incidence of five major cancers in Nepal, 2012. Nepal J Epidemiol. 2016;6(2);565-73. [DOI]

8. Amatya A, Rana A, Gurung G. Ovarian tumors in childhood and adolescents - our eight years experiences. NJOG. 2008 May-Jun;3(1):39-42. [DOI]

9. Jha $\mathrm{R}$, Karki S. Histological pattern of ovarian tumours and their age distribution. Nepal Med Coll J. 2008;10(2):81-5.[PubMed]

10. Kayastha S. Study of ovarian tumors in Nepal Medical College Teaching Hospital. Nepal Med Coll J. 2009;11(3):200-2. [PubMed]

11. Sah SP, Uprety D, Rani S. Germ cell tumours of the ovary: A clinicopathologic study of 121 cases from Nepal. J Obstet Gynaecol Res. 2004;30(4):303-8. [DOI]

12. Pradhan A, Sinha AK,Upreti D.Histopathological patterns of ovarian tumors at BPKIHS. Health Renaissance. 2012;10(2):87-97.[DOI]

13. Bista KDB. Incidence, histological types and age at presentation of borderline and malignant ovarian tumors at a tertiary institute in Nepal. NJOG. 2014 Jul-Dec;18 (2):11-6.[DOI]
14. Mohammad A, Makaju R. Retrospective histopathological analysis of various neoplasms of the female reproductive system (FRS) seen at Kathmandu University Teaching Hospital (KUTH), Dhulikhel, Nepal. Kathmandu University Med J. 2006;4(1);13;48-53.[PubMed]

15. Pudasaini S, Lakhey M, Hirachand S, Akhter J, Thapa B.A study of ovarian cyst in a tertiary hospital of Kathmandu valley. Nepal Med Coll J.2011;13(1):3941. [PubMed]

16. Ahmad Z, Kayani N, Hasan SH, Muzaffar S, Gill MS. Histological pattern of ovarian neoplasm. J Pak Med Assoc. 2000;50:416-9. [Full Text]

17. Koonings PP, Campbell K, Mishell DR Jr, Grimes DA. Relative frequency of primary ovarian neoplasms: a 10-yearreview. Obstet Gynaecol. 1989;74:921-6.

18. Gopeesingh TD, Rahaman J, Charran DA. Clinicopathologic study of ovarian neoplasm. Int J Gynaecol Obstet. 1988;26:413-6.

19. Pilli GS, Suneeta KP, Dhaded AV, Yenni VV. Ovarian tumours: a study of 282 cases. J Indian Med Assoc. 2002;100:420,423-4,447.

20. Merino MJ, Jaffe G. Age contrast in ovarian pathology. Cancer. 1993;71:S537-44.

21. Di Bonito L, Patriarca S, Delendi M, Alberico S. Ovarian tumours: anatomohistopathological contribution to their interpretation. Eur J Gynaecol Oncol. 1988;9:324-30. [PubMed]

22. Amatya S, Gurung G, Rana A. Annual clinicopathological analysis of ovarian tumours at TUTH. NJOG. 2010 Jan-Feb;4(2):18-24.

23. El-Yahia AR, Rahman J, Rahman MS, al-Suleiman SA. Ovarian tumours in pregnancy. Aust N Z J Obstet Gynaecol. 1991 Nov;31(4):327-30.[PubMed] 